\title{
遅発性外傷性脳内血腫に対するDICの関与
}

\author{
澤田 祐介・阪本 敏久・定光 大海・西出 和幸・池邨 勝美・吉岡 敏治 \\ 杉本 㑆
}

\section{Delayed Traumatic Intracerebral Hematoma}

\section{Relation to Disseminated Intravascular Coagulation}

Yusuke Sawada, Toshihisa Sakamoto, Daikai Sadamitsu, Kazuyuki Nishide, Katsumi IkemurA, Toshiharu YoshiokA and Tsuyoshi Sugimoto

Department of Traumatology, Osaka University, Osaka

\begin{abstract}
Eighteen patients of delayed traumatic intracerebral hematoma (DTICH) were experienced among 268 head injured patients seen over a 32 month period. The interval from the admission computerized tomography (CT) to CT diagnosis of DTICH varied from eight hours to 13 days. All patients were comatose on admission. Three had acute epidural hematoma (EDH), one brain prolapse, and 17 exhibited acute subdural hematoma. Thirteen patients, including three EDH cases received evacuation of hematoma and craniectomy (external decompression) while the remaining five were not operated on but were treated with barbiturates to prevent or reduce intracranial hypertension.

All the patients had laboratory studies for disseminated intravascular coagulation (DIC) over 7 days. The parameters were platelet counts (PC), active partial thromboplastin time (APTT), prothrombin time (PT), serum fibrinogen, fibrin degradation products (FDP), and protamine sulphate test (PS-test). All the patients showed severe hypofibrinogenemia during the first 24 hours which recovered abruptly to beyond the normal range within the next 24 hours. Hyperfibrinogenemia continued for at least seven days after trauma. PC's were almost normal on admission but decreased promptly within 24 hours and remained low for the following four days. All cases revealed low or borderline level PT throughout the monitoring period, while APTT revealed n,o abnormalities. These and serum FDP and PS-tests revealed no statistically significant difference between DTICH cases and controls.

DTICH was found either in coup or contre-coup lesions along the extension line of impact, and the initial CT demonstrated abnormal densities in 14 (low, or salt \& pepper) and normal in four. It was concluded that DIC was not responsible for the development of DTICH while primary direct contusion was a major factor in its evolution.
\end{abstract}

Key words: delayed traumatic intracerebral hematoma, disseminated intravascular coagulation, computed tomography, head injury, decompressive surgery

\section{I はじめに}

頭部外傷に対する computed tomography（CT) 検査，特 に serial CT の普及に伴い, 遅発性外傷性脳内血腫( de- layed traumatic intracerebral hematoma : DTICH) が注目 を集め，その発生嚬度・機序抢よび病態についての報告が 相次いでいる。ながも発生機序に関して，全身疾患である 汎発性血管内凝固症侯群 (disseminated intravascular coagu-

大阪大学特殊救急部

Address reprint requests to: Y. Sawada, M. D., Department of Traumatology, Osaka University, 1-1-50 Fukushima, Fukushima-ku, Osaka 553.

受稿 1983 年 1 月 31 日 受理 1983 年 5 月15日 
lation：DIC）との関連が強く疑われ，症例報告とともに 抗凝固剤投与による予防にまで言及寸る論文もみられ，現 在積極的研究が推進されている。

本稿では，自験18例の DTICH 症例につき routine の凝 固・線溶系検查結果を対照44例と比較し，DIC と DTICH の関係を検索するとともに，CT 所見を中心としてその発 生機序について検討を加えた。

\section{II 対象および方法}

本稿に㧍けるDTICH は全例 CTによる部断であり，来 院時 CTにより iso-(normo-) density, low-density \&しく は salt \& pepper であった部位に，8時間以降のserial CT により脳実質内の high-density area の出現むしくは進展を 認ぬた例，との Gudeman らの定義に從 う例を指す ${ }^{6}$. 1980 年 3 月より 1982 年 10 月までの 2 年 8 力月間仁当科入院 となった268例の頭部外傷患者中，上述の criteriaに合致す るDTICH は18症例存在し，これらを対象とした。

年龄は $1 \sim 80$ 才，平均 $31.6 \pm 20.7$ 才であり，男性14例， 女性 4 例であった．全例受甥後 2 時間以内に当科入院とな って扔り，来院時の意識レベルは Glasgow Coma Scale (GCS) 亿て10以下，平均 6.3土2.0であった。穿頭術下にク モ膜下カテーテル法にて測定した頭蓋内圧 (ICP) は $8 \sim 58$ $\mathrm{mmHg}$, 平均 $29.4 \pm 14.7 \mathrm{mmHg}$ であり, $10 \mathrm{mmHg}$ 以下 1 例, $11 \sim 20 \mathrm{mmHg} 6$ 例, $21 \sim 40 \mathrm{mmHg} 6$ 例, $41 \sim 60$ $\mathrm{mmHg} 5$ 例であった. Table 1 亿対象18例を示す。これら は initial CT 所見挍よび術後経過により，1３日の間 隔で serial CT を施行した. Retrospective に DTICH 発見 時の CT 酝ial CT と比較し, DTICH 発生部位の initial CT に招汀万異常の有無, 直達外力扔よび手術との 関保につき検討を加えた。

凝固・線溶采異常に対する血液学的検查は, 当科に扔汀 る routine 検查 6 項目 (血小板数; PCs，プロトロンビン時 間；PT，活性部分トロンボプラスチン時間；APTT，血汻 フィブリノーダン(fibrinogen), フィブリン変性産物; FDP，プロタミン・スルフェイト試験；PS-test)を1日1 回連続 8 日間行った。これらの検查成績とDTICH発生と の関係をるるめ，同時期に入院した GCS 10以下の，頭 部以外に重篤な合併損傷のない単独頭部外傷 20 例 (Group II ), 頭部以外飞一側の長管骨骨折以上の重篤な損甥を伴 5 合併頭部外傷24例 (Group III) 対照として同一の検査を 行い，先のDTICH 18例をGroup I として，抎の抬の 2 群 間につき $\chi^{2}$ 分布に上り統計学的検討を行った。

1 例を除く17例に急性硬膜下血腫が認められ，5ち3 例 に硬膜外血腫, 1 例に脳脱出が合併していた. 硬膜外血 腫・脳脱出合併例を含む13例に対し血腫除去術, 片側広汎
Table 1 Clinical materials

\begin{tabular}{|c|c|c|c|c|c|c|}
\hline Case & Age & Sex & $\begin{array}{l}\text { Glas- } \\
\text { gow } \\
\text { Coma } \\
\text { Scale }\end{array}$ & $\underset{(\mathrm{mmHg})}{\mathrm{ICP}}$ & $\begin{array}{l}\text { Interval } \\
\text { from } \\
\text { admis- } \\
\text { sion to } \\
\text { DTICH } \\
\text { diagnosis }\end{array}$ & Outcome \\
\hline 1 & 40 & $\mathbf{M}$ & 7 & 27 & $48 \mathrm{hrs}$ & $\mathrm{D}$ \\
\hline 2 & 16 & $\mathbf{M}$ & 4 & 18 & $36 \mathrm{hrs}$ & Veg. \\
\hline 3 & 1 & $\mathbf{F}$ & 6 & 46 & 13 days & Veg. \\
\hline 4 & 19 & $\mathbf{M}$ & 3 & 19 & 3 days & $\mathrm{D}$ \\
\hline 5 & 25 & $\mathbf{M}$ & 7 & 14 & $40 \mathrm{hrs}$ & D \\
\hline 6 & 44 & M & 9 & 40 & $12 \mathrm{hrs}$ & D \\
\hline 7 & 80 & $\mathrm{~F}$ & 7 & 22 & $30 \mathrm{hrs}$ & $\mathbf{D}$ \\
\hline 8 & 1 & $\mathbf{M}$ & 5 & 24 & 7 days & MD \\
\hline 9 & 27 & $\mathbf{M}$ & 7 & 42 & $14 \mathrm{hrs}$ & MD \\
\hline 10 & 53 & $\mathbf{M}$ & 7 & 19 & $25 \mathrm{hrs}$ & $\mathrm{D}$ \\
\hline 11 & 49 & $\mathbf{F}$ & 4 & 14 & $42 \mathrm{hrs}$ & $\mathrm{D}$ \\
\hline 12 & 7 & $\mathbf{M}$ & 9 & 25 & $46 \mathrm{hrs}$ & $\mathrm{MD}$ \\
\hline 13 & 34 & $\mathbf{M}$ & 10 & 58 & $27 \mathrm{hrs}$ & $\mathrm{D}$ \\
\hline 14 & 45 & $\mathbf{M}$ & 4 & 8 & 4 days & $\mathrm{SD}$ \\
\hline 15 & 19 & $\mathbf{M}$ & 8 & 38 & $8 \mathrm{hrs}$ & GR \\
\hline 16 & 46 & $\mathbf{M}$ & 5 & 51 & $27 \mathrm{hrs}$ & $\mathrm{D}$ \\
\hline 17 & 47 & $\mathrm{~F}$ & 5 & 18 & $38 \mathrm{hrs}$ & $\mathrm{D}$ \\
\hline 18 & 16 & $\mathbf{M}$ & 7 & 46 & 12 days & $\mathrm{SD}$ \\
\hline
\end{tabular}

ICP indicates intracranial pressure; DTICH, delayed traumatic intracerebral hematoma; $D$, death; Veg., vegetative state; SD, severe disability; MD, moderate disability; GR, good recovery.

外減圧術を行い，急性硬膜下血腫を認めなかった 1 例を含 む残り5例に対しては ICP 減圧および京進予防の目的で barbiturate 療法を行った. Barbiturateは超短時間作用薬で ある thiamylal (Isozol ${ }^{\circledR}$ ) を用いた. 当科では ICP $30 \mathrm{mmHg}$ を critical level と考えて抢り，30 $\mathrm{mmHg}$ 以上の症例に対 しては thiamylal $15 \mathrm{mg} / \mathrm{kg} / 15 \mathrm{~min} 1$ 回投与後, 媨波上 suppression-burst pattern の維持を目標に $4 \sim 6 \mathrm{mg} / \mathrm{kg} / \mathrm{hr}$ を72時間連続投与し，ICP $21 \sim 30 \mathrm{mmHg}$ に対しては $5 \mathrm{mg} /$ $\mathrm{kg} / 5 \mathrm{~min} 1$ 回投与後, ICP モニター下に $30 \mathrm{mmHg}$ 以下を 目標として 1 2 mg/kg/hr 72時間投与した.

DTICH 発見後，6例住して血腫除去術を施行し， ICP 六進に対して性上述の barbiturate 療法を同様の基淮 に徉い施行した。予後は受傷後 3 力月の時点に捛いて, Glasgow Outcome Scale(GOS)に上って判定した.

\section{III 結 果}

\section{1. 凝固・線溶系検查}

Fibrinogen：3群62例中56例が，来院時検查に抒いて $200 \mathrm{mg} / \mathrm{d} l$ 以下の hypofibrinogenemia を示した.この hy- 


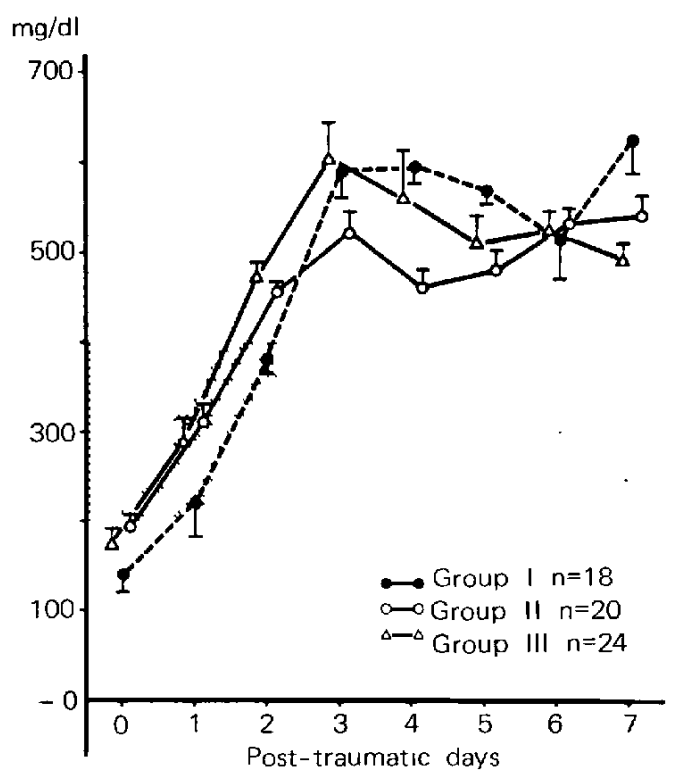

Fig. 1 Changes of serum fibrinogen in the early posttraumatic poriod. All the patients showed severe hypofibrinogenemia during the first 24 hours after trauma but recovered to beyond the normal range within the second 24 hours. Group I, or the 18 cases of delayed traumatic intracerebral hematoma, is comparcd with Group II, or 20 cases of head injury without associated significant injury, and Group III, or 24 cases of head injury with associated significant injuries. All three groups were rated 10 or under by the Glasgow Coma Scale.

pofibrinogenemia は24時間以内に48例(85.7\%)が，さらに 48時間以内に全例吕正常值もしくは正常域值以上一と上昇 し，Fig. 1 にみるごとく,第7病日までむしろ hyperfibrinogenemia の状態索した。いずれの2群間にも，全検查 期間を通じて統計学的有意差は認められなかった。

PCs：来院時に法正常域下限にある例が多く認められた ものの，第 1 病日には52例 (83.9\%)が150,000/ $\mathrm{mm}^{3}$ 以下一

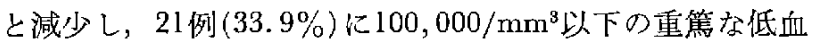
小板血症が認められ，以後 1 週間の検查期間を通じ正常域 下限もしくは異常低值をとり続ける症例が多くみられた。 Fig. 2 に示すごとく, standard error が大きく統計学的有 意差はいずれの 2 群間にも認奻られなかった。

$\mathbf{P T}$ : 全検査期間を通じて大幅な変化は認められず, 正常域下限もしくは異常低值をとり続けた。3群間汇統計 学的有意差は認められなかった。Fig. 3 にPTの変動を示 す.

APTT : 特に受傷早期に括いてその変動が大きく，変 化に対する一定の傾向すら促えることはできなかった． Fig. 4 に APTT の変化を示す。当科に打けるAPTTの

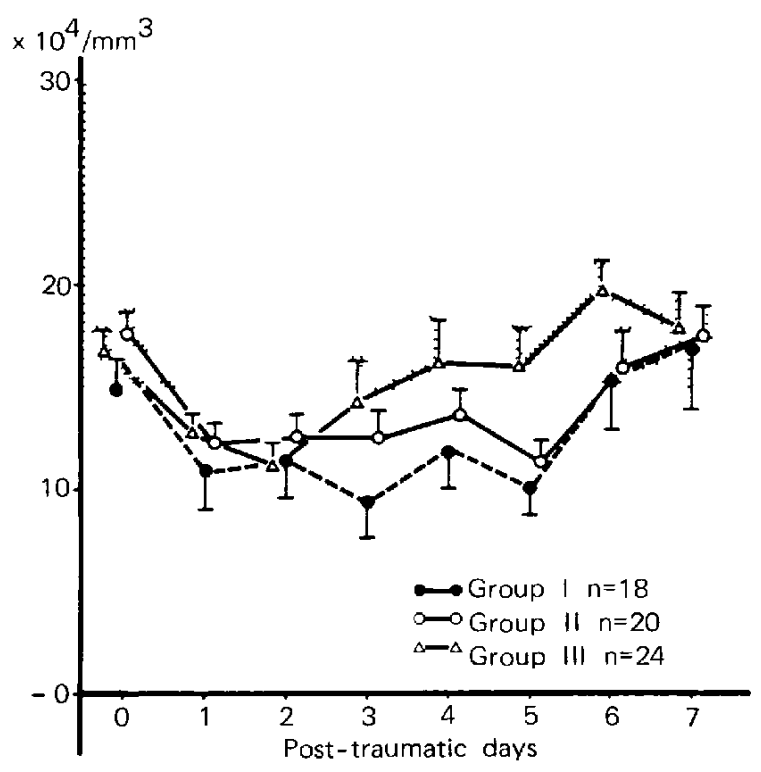

Fig. 2 Daily changes of platelet counts. Platelet counts were almost within normal range on admission, decreased promptly within the first 24 hours, and on the following 4 days abnormal levels were maintained.

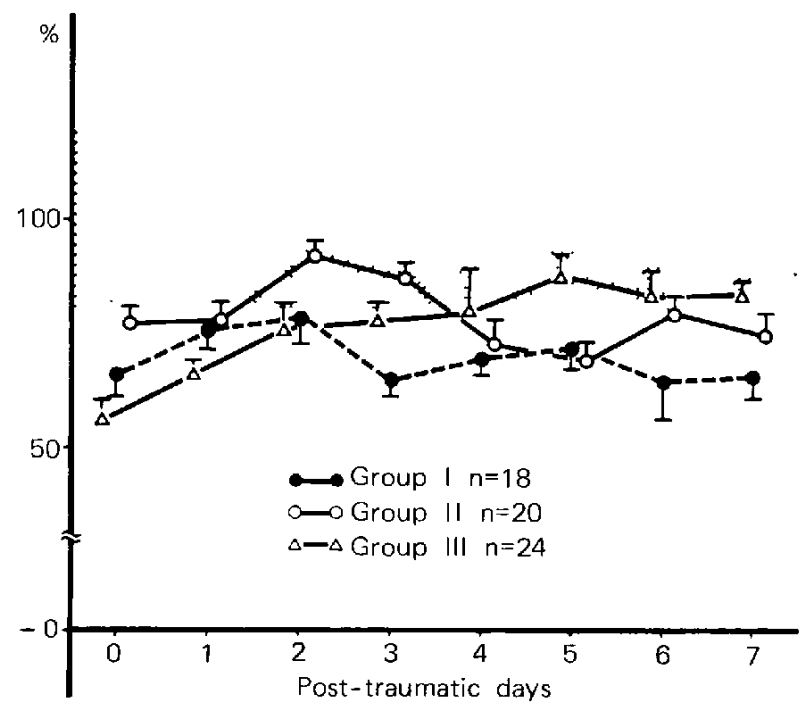

Fig. 3 Daily changes of prothrombin time, Low or borderline levels were maintained throughout the period in all three groups.

正常域は $25 \sim 45$ 秒であり，全症例につき異常值を示した時 期は認めら的ず，統計学的有意差も認められなかった。

FDP \& PS-test : FDP $20 \mu \mathrm{g} / \mathrm{m} l$ 以上の異常值検出率 お 上び PS-test 陽性率を Table 2 に示す. 検查期間内で注 Group I が両者とももっとも低い率を示したが，両者間に 統計学的有意差は認められなかった。 


\section{2. $\mathbf{C T}$ 所見}

DTICH 発生部位につき，発見時 CT と initial CT との 比較，および直達外力，手術との関倸について検討を加え た. 今回の定義に基づく DTICH は23力所记発見したが，

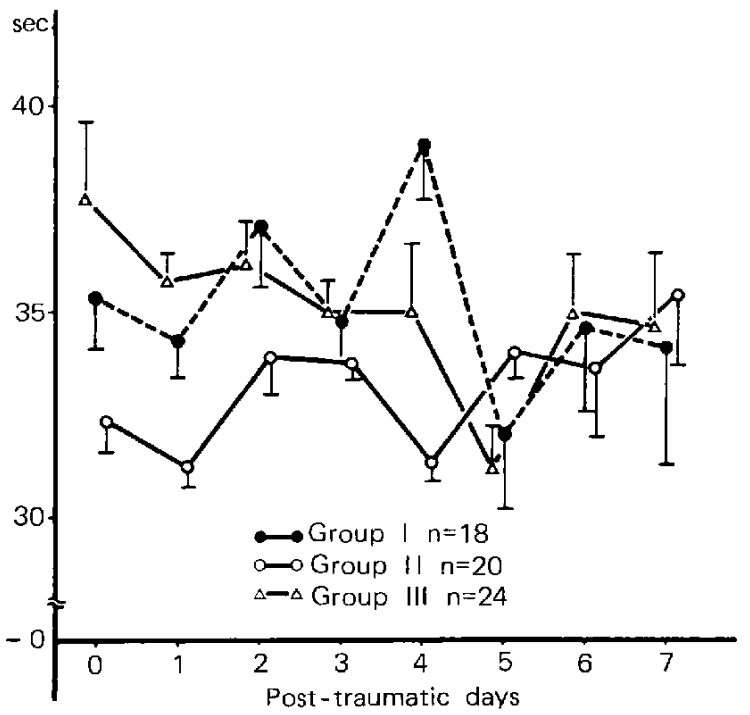

Fig. 4 Daily changes of active partial thromboplastin time. The values are erratic, but all are within normal range.
$5 ち 6$ 力所以 initial CT 上の normo-density area, 3 力所 は low-density area，残る14カ所はすべて salt \& pepper area に発生していたことが retrospective に判明した。 また 11 力所法直達外力直下 (coup lesion)，12力所法直達外力対 側 (contre-coup lesion) に発生をみ，13例纪対し血腫除去 術と同時に片側広汎外減圧術を施行したが，うち11例(84.6 $\%) 17$ 力所中 11 力所 $(64.7 \%$ ) に減圧側対側の DTICH の発 生を認めた. 非手術 5 例では 6 カ所にDTICH の発生を認 め，5ち直達外力対側への発生は 1 例 1 力所 $(20.0 \%)$ であ った。 また18例23力所の DTICH 法，いずれも直達外力延 長線上に扔汀る発生であった。 Fig. 5 に減圧術施行・非施 行例別に直達外力と DTICH 発生部位との関倸，および initial CT 所見を示L, Fig. 6 K normo-, low-, salt \&

Table 2 Number of patients with positive protamine sulfate test and with elevated serum FDP*

\begin{tabular}{lccc}
\hline & Group I & Group II & Group III \\
\hline PS-test & $1(5.6 \%)$ & $4(20.0 \%)$ & $5(20.8 \%)$ \\
FDP & $3(16.7 \%)$ & $5(25.0 \%)$ & $7(29.2 \%)$ \\
$(\geqq 20 \mu \mathrm{g} / \mathrm{m} l)$ & $\mathrm{n}=18$ & $\mathrm{n}=20$ & $\mathrm{n}=24$ \\
\hline
\end{tabular}

* within 7 days after trauma.

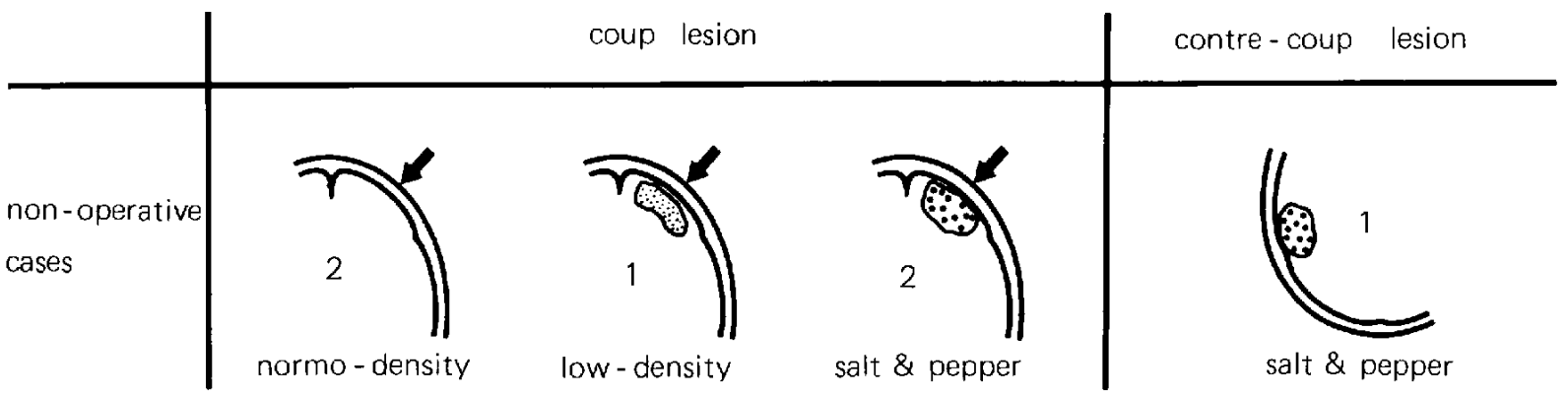

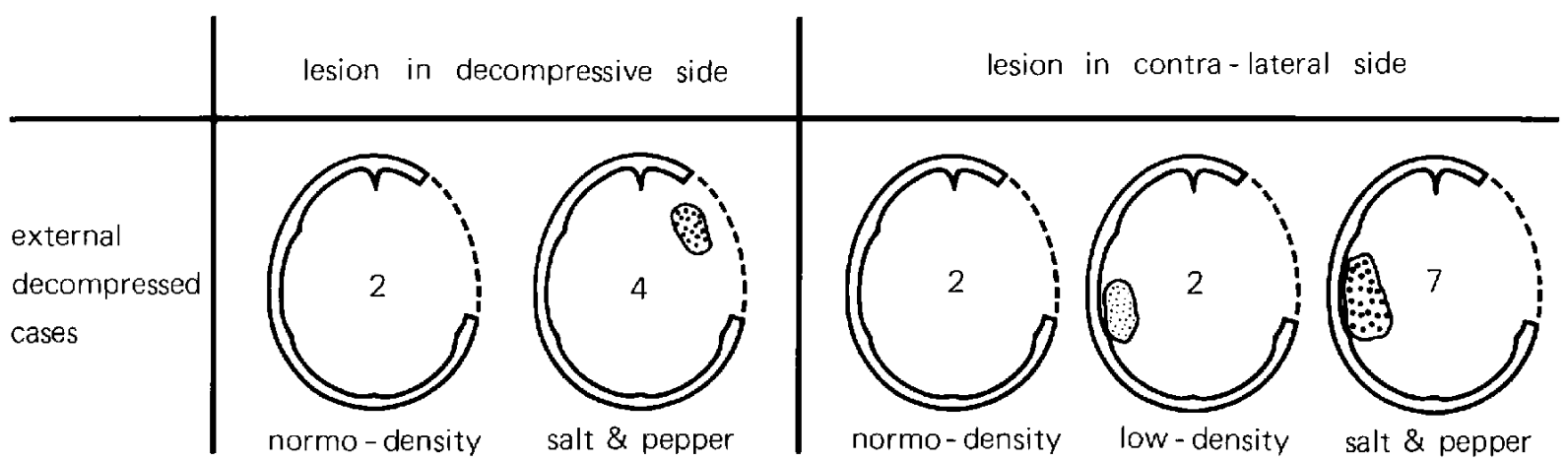

Fig. 5 Initial lesions of delayed traumatic intracerebral hematoma (DTICH) both in surgically decompressed and in non-operated cases. Note that in the surgically decompressed cases. There are more cases of DTICH in the contre-coup region. Arrows indicates impact, and number indicates no. of cases. 

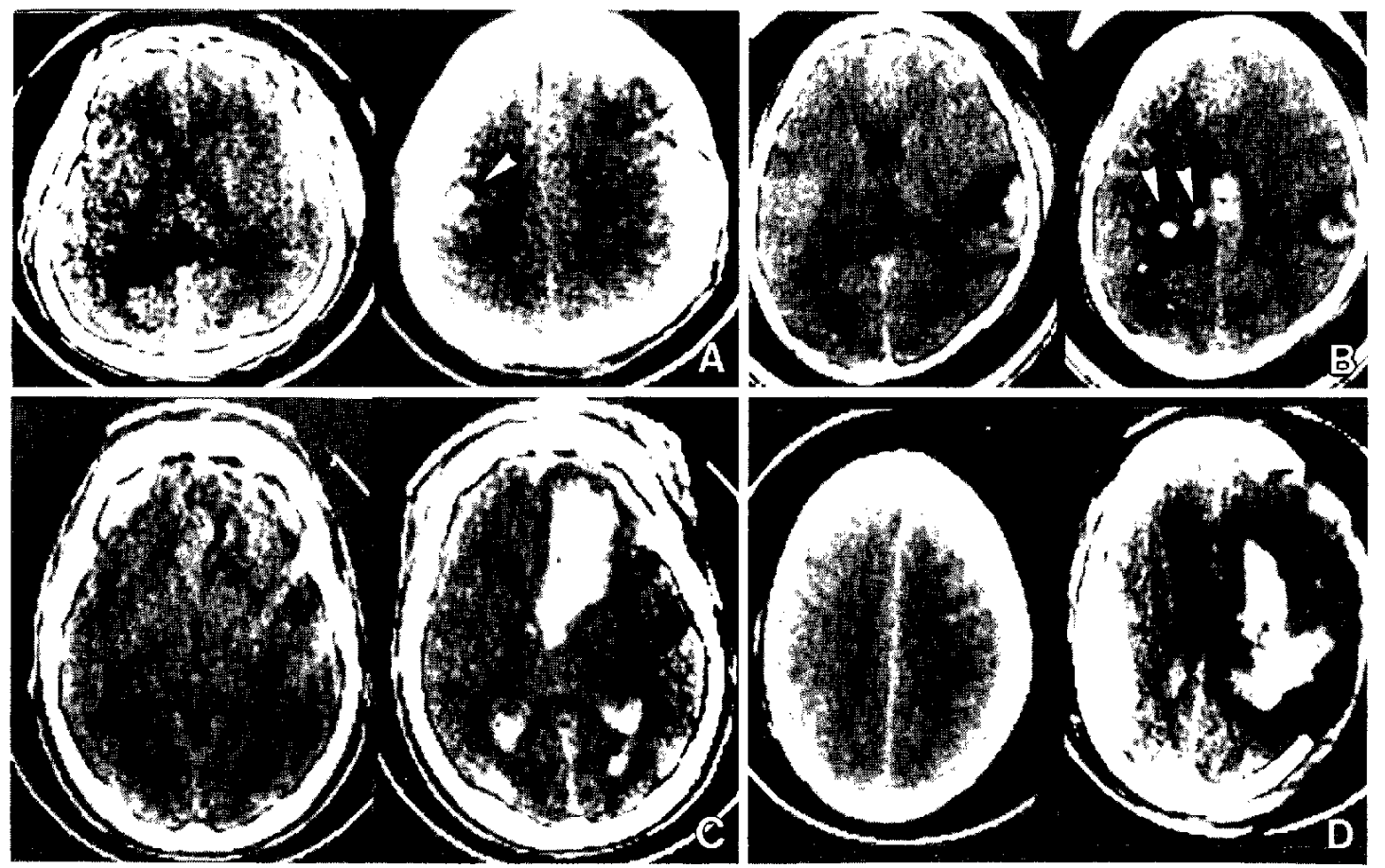

Fig. 6 DTICHs in various areas. A: DTICH in normo-density area shown as a small asymptomatic hematoma (arrowhead). B: DTICH in low-density area shown as multiple small hematomas (arrozeheads). C: DTICH in salt \& pepper arca. This was the only case in which the intracranial pressure was markedly elevated and consciousness was deteriorated. D: DTICH after surgical decompression. Giant DTICH in the decompressed side and a large epidural hematoma in the contra-lateral side.

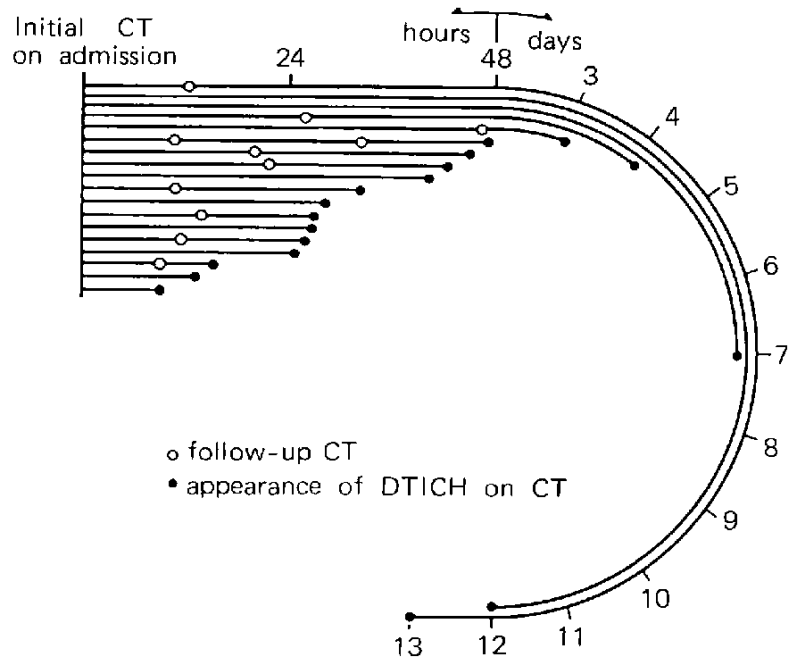

Fig. 7 Interval from admission CT to CT diagnosis of DTICH.

pepper area おのおのに生じた DTICH の代表例と，広汎 減圧術後に生じた巨大例を示す。

\section{DTICH 発見時期および予後}

Fig. 7 にDTICH発見までの期問，およびその問のserial
CT 施行日時を示す。発見時期注最短 8 時間，最長 13 日で あり，13例(72. $2 \%)$ が48時間以内に発見されている。詳細 に検討すると，数日以上を経た発見例は最初の serial CT までの期間が長く，真の発生時期とは大きく加灕れてい る可能性が否定できない，発見の契機を検討しても，ICP の上昇もしくは意識レベルの急激な変化を契機とした例は わずか 1 例のみであり，血腫自体の大きさ，手術後麻酔の 遷延，barbiturate 療法による意識レベルの低下などを考慮 しても，臨床所見により DTICH発生が疑われる症例法少 なく，残る17例はすべて予定された serial CTにより偶然 発見されたものであった，予後注きわめて不良であり， GOS 比よる good recovery 1 例, moderate disability 3 例, severc disability 2 例, vegetative state 2 例, dead 10 例であ った.

\section{IV 考察}

DTICH の成因の…として，破壊的脑損傷に続発する DICの関与が想定されている，外傷患者に杍行るDIC は hypoxia, hypotension, 損傷臟器よりの組織トロンボプラ スチンの放出などの諸因子の合併により惹起されるものと 考えられている ${ }^{2\rangle}$. 周知のご上く, 脳は全器官のうちでも 
もっとも組織トロンボプラスチンの豊富な蔵器であり1， 組織破壊を伴う重篤な脳損傷を引き金として DIC が生じ るとの推論はきわめて蓋然性の高いものと文える，事実， 重症頭部外傷後に生じた急激な DIC 例の経験は, 多くの 症例報告または series として発表されている, かし control studyのない従来の検討からは，全身的な凝固 -楾溶系の破綻, 乏の終末像としてのDIC と頭蓋内に限 局した局所的出血の臨床像としての DTICHとの直接的因

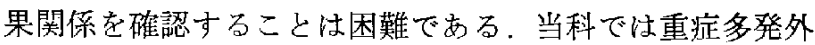
傷, 敗血症, 産後の急性腎不全などに併発する DIC 症例 を数多く経験する機会に遭遇するが，それら症例において は例外なく血管穿刺部位，手術㓣などよりの遷延する出血 をはじめとして，bed-side に掠いて確認しらるいおゆる易 出血傾向が多少とも認められる。一方今回対象とした DTICH 18例に関しては，そのような episode は1例もな 加た。この経験に基ゔき，DTICH 発生に対するDIC の関与につき本研究を行った。

当科泟讨西凝固・線溶系の routine 検查 6 項目につW ては，対照とした 2 群いずれとの間にも統計学的有意差は まったく認められなかった (Fig. 1 4, Table 2). DTICH 18例には単独・合併頭部外傷双方が含まれているためその 両者を対照とし，頭部外傷の injury severityについては GCS に上って症例間の均一化を図った。

3 群に共通して認められた凝固・線溶系の異常，すな⿰ ち第 1 病日以降にみられる $\mathrm{PCs} の 大$ 幅な低下, $\mathrm{PT}$ の持続 する低值，fibrinogen の急激な上异などの変化は，けっし て頭部外傷例に特有な変化ではなく，広沉重症熱 傷患者 を含む重度外傷患者に一般的に広く認められる現象であ $る^{3,91}$ ，内因系異常を示すとされるAPTT が全期間を通じ 正常域内にとどまるのに対し，外因系異常を反映するとさ れるPTが低值をとり続ける事実は，外傷により凝固・線 溶系になんらかの破綻が生じたことを示唆する。一方，大 量の消費を意味していると思われる極端な hypofibrinogenemia 江24時間以内に急速に回復してきており，生合成 能は速やかに反忘し，明らかに合成が消費を上回っている 事実を示している．脳損傷後の凝固・線溶采異常に対して Preston らは早期よりヘパリン療法を唱え ${ }^{122}$, Goodnightら は fibrinolysisを増強させるとしてへパリン使用を禁忌であ

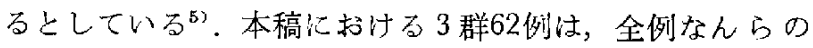
抗凝固剂を使用することなく受傷後 1 週閒以内にほぼ正常 域一と回復して拉り，この間臨床的に易出血傾向索認めた 例はなかった。我々は，こらした臨床的に易出血傾向の認 められない凝固・線溶系の異常検查值は重度外傷, 特にシ ヨックの “爪跡”であり，生体の防御反応としての凝固・ 線溶采両者のバランスのとれた亢進の結果であると考えて
おり?，このバランスを崩す特異的薬郕の使用には否定的 立場をとっている13).

今回の我々の検討からは，DTICH の直接的引き金とな る要因を断定することはできなかった。しかしながら， DTICH がすべて CT 上直達外力延長線上に限って発生し たこと, initial CT 上 low-density もしくは salt \& pepper area よりの発生, Tsubokawa 0 分類 ${ }^{14)}$ による hematoma with contusion が23力所中19力所 $(82.6 \%$ )に認められたこ とは，DIC上いった全身的疾患より，むしろ受傷時点に扔 いてすでに生じていた局所的病変に由来するものであるこ とを強く示唆する結果であった。

本検討中我々が興味を持った事実の一つは，隇圧術施行 例に㧍けるDTICH の発現, 特に減圧側対側一の本病変の 発生である. Low-density area 2 例, normo-density area 2 例, salt \& pepper area 7 例の計11例の発生は, contre-coup region 全12例の $91.7 \%$ に度ふ。この発現頻度に対して 注，症例数が少ないことや十分な対照がないことから，統 計学的検定はなし党なかった。しかし発生部位の局在性加

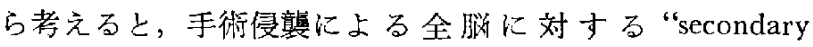
accident” ${ }^{67}$ を考慮するより，むしろ機械的堿圧による赤血 球漏出，も乙くは毛細血管の破綻に起因卞る出血 ${ }^{8)}$ 強く 疑わしめた. DTICH 発生といら観点より, 今後広沉減圧 術の再検討がなされるべきことを痛感した。

\section{$\mathrm{V}$ 結 語}

DTICH に対するDIC の関与を検討した。DTICH 18 例㧍よび対照44例に対し，受傷後 8 日間の㠜固・線溶系検 查を実施するとともに，initial CT 扝よび serial CT の比 較検討より，その発生機序につき考察を加えた，当科に拀 け子凝固 - 線溶系の routine 検查 (PCs, PT, APTT, fibrinogen, FDP, PS-test)の成績からは, DTICH 群と対照 群との間になんらの統計学的有意差を見い出すことはでき ず，DTICH の発生汅対し凝固・線溶系の破緃が直接的影 響を与光る上は到底考えられなかった。 DTICH 発生部位 は直達外力姃長線上に局在して拉り，CT の検討から局所 の潜在的障害が, 手術例の検討から庆汎減圧術の関与が示 唆された。

\section{文献}

1) Astrup T: Assay and content of tissue Thromboplastin in defferent organs. Thromb Diath Haemorrh 14: 401-416, 1965

2) Bell WR: Disseminated intravascular coagulation. Johns Hopkins Med $J$ 146: 289-299, 1980

3) Borowiecki B, Sharp AA: Trauma and fibrinolysis. $J$ Trauma 9: 522-536, 1969 
4) Brown FD, Mullan S, Duda EE: Delayed traumatic intracerebral hematoma. $J$ Neurosurg 48: 1019-1022, 1978

5) Goodnight SH, Kenoyer G, Rapaport SI, Patch MJ, Lee JA, Kurze T: Defibrination after brain-tissue destruction. A serious complication of head injury. $N$ Engl $J$ Med 290: 1043-1047, 1974

6) Gudeman SK, Kishore PRS, Miller JD, Girevendulis AK, Lipper MH, Becker DP: The genesis and significance of delayed traumatic intracerebral hematoma. Neurosurgery 5: 309-313, 1979

7) Hardaway RM: Shock and disseminated intravascular coagulation. Thromb Diath Haemorrh 20 [Suppl] : 121-146, 1966

8) Hirsh LF: Delayed traumatic intracerebral hematoma after surgical decompression. Neurosurgery $5: 653-655,1979$

9）池邨勝美, 伏見 了, 甲田一馬, 林 長蔵, 宮井 潔, 寒川[昌明，吉岡敏治，杉本 㑆: 多発外傷および広範囲熱 傷の初期における血液㠜固・線溶機能，臨病理 31:634 638,1983

10) Kaufman $\mathrm{H}$, Moake JL, Olson JD, Miner ME, du Cret RP, Pruessner JL, Gildenberg PL: Delayed and recurrent intracranial hematomas related to disseminated intravascular clotting and fibrinolysis in head injury. Neurosurgery 7: 445-449, 1980

11) Keimowitz RM, Annis BL: Disseminated intravascular coagulation associated with massive brain injury. $J$ Neurosurg 39: 178-180, 1973

12) Preston FE, Malia RG, Sworn MJ, Timperley WR, Blackburn EK: Disseminated intravascular coagulation as a consequence of cerebral damage. $J$ Neurol Neurosurg Psychiatry 37: 241-248, 1974

13) 杉本 㑆：外傷患者の出血㑯向 一その原因に対する新 しい解秎の試み一。今日の医学 $54: 57-66,1973$

14) Tsubokawa $T$ : Two types of delayed post-traumatic intracerebral hematoma. Neurol Med Chir (Tokyo) 21: $669-675,1981$

15) Vecht CHJ, Sibinga THS, Minderhoud JM: Disseminated intravascular coagulation and head injury. $J$ Neurol Neurosurg Psychiatry 38: 567-571, 1975

〔別刷請求先： $\mathbf{T} 553$ 大阪市福島区福島 1-1-50, 大阪大学特 殊救急部, 澤田䀡介] 